\title{
From Apologetics to Polemics: Isaac Orobio's Defences of Judaism and their Uses in the French Enlightenment
}

Histories of the intellectual interaction between Jews and Christians in the early modern period have generally been written in an ameliorative mode, highlighting the gradual rise of a more civil tone in theological exchanges over the course of the seventeenth and eighteenth centuries. This has particularly been the case in studies of seventeenth-century Amsterdam. A particularly good example is the pioneering work of Ralph Melnick, who, in his book From Polemics to Apologetics: Jewish-Christian Rapprochement in Seventeenth-Century Amsterdam (1981), ${ }^{1}$ made his argument very clear in his choice of title. And that argument is very defensible.

The first text Melnick discusses was written in Portuguese by Elijah Montalto, the first significant Sephardic anti-Christian polemicist. His refutation of the Christian interpretation of the fifty-third chapter of Isaiah probably originated in Venice around $1610 .^{2}$ This extremely polemical text never directly names its target: Christians are always periphrastically but scathingly referred to as the "Slanderers of the Divine Law" (os depravadores da Divina Ley). ${ }^{3}$ Montalto argues uncompromisingly against numerous tenets of Christian belief, such as original sin, and identifies and ridicules various contradictions and inconsistencies in the gospels, drawing on a detailed knowledge of the New Testament gained during his marrano past. ${ }^{4}$ Montalto died in Paris in 1616 as he was serving as doctor to Queen Regent Marie de Médicis. His student Saul Levi Mortera brought his body and his polemical text to Amsterdam, and later himself became a leading rabbi in the Amsterdam community. Mortera also wrote several anti-Christian polemics in which he vigorously confronted various key points of friction between Judaism and Christianity, such as the nature of sin and salvation, the Trinity, and the issue of the Messiah. These circulated quite widely among the Sephardim of Amsterdam alongside Montalto's text,

Adam Sutcliffe, King's College London

1 Ralph Melnick, From Polemics to Apologetics: Jewish-Christian Rapprochement in Seventeenth-Century Amsterdam (Assen: Van Gorcum, 1981).

2 Jonathan I. Israel, European Jewry in the Age of Mercantilism, 1550-1750 (Oxford: Clarendon Press, 1985), 84-85; Ralph Melnick, From Polemics to Apologetics, 24-28; Bernard Cooperman, "Eliahu Montalto's ‘Suitable and Incontrovertible Propositions,'” in Jewish Thought in the Seventeenth Century, edited by Isadore Twersky and Bernard Septimus (Cambridge: Harvard University Center for Jewish Studies, 1987): $469-497$.

3 Eliahu Montalto, Tractado do Doctor Montalto Sobre o principio do Capitulo 53 de Jesaias; University Library of Amsterdam, MS Ros 76.

4 Eliahu Montalto, Tractado do Doctor Montalto Sobre o principio do Capitulo 53 de Jesaias, 5, 73-76.

Ә OpenAccess. (c) 2018 Adam Sutcliffe, published by De Gruyter. (c) BY-NC-ND This work is licensed under the Creative Commons Attribution-NonCommercial-NoDerivatives 4.0 License. 
where they served to shore up Jewish commitment and pride among doubters in the community. $^{5}$

As Melnick highlights, the highly assertive and uncompromising texts of Montalto and Mortera contrast greatly with the mood elsewhere in Amsterdam. As commercial contacts between Sephardic Jews and Christians became closer-particularly from the 1650s onwards, due to the booming Dutch colonial trade with the West Indies $^{6}$ - social and intellectual interchange also grew more amicable and commonplace. The meticulously detailed model of Solomon's Temple built in the 1640s by Rabbi Jacob Jehuda Leon (1602-1675) fascinated Jews and Christians alike and for several decades attracted large numbers of visitors in both Holland and England. ${ }^{7}$ In the middle years of the seventeenth century, a mood of millenarian excitement led to extremely fervid interest in all things Jewish among radical Christians in Holland in particular, as the works of Richard Popkin and several other scholars have shown. Members of a tight Anglo-Dutch, philo-Judaic circle, including the Amsterdam millenarian Petrus Serrarius and the Middelburg Hebraist Adam Boreel; in England, John Durie, Samuel Hartlib, and others were involved in a number of other Hebraistic projects, including translations of the Mishnah into Latin and of the New Testament into Hebrew as well as the collection of funds for the Jewish community in Jerusalem. ${ }^{8}$

Isaac Orobio, who arrived in Amsterdam in 1662, was also far from being a simple polemicist against Christianity. He was respected by Christians as an interlocutor, ${ }^{9}$ as was underscored by the appeal made to him by the radical and troubled Collegiant Jan Bredenburg who was trying to write a refutation of Spinoza's arguments and eventually found himself persuaded by them-this encounter gave rise to Orobio's Certamen Philosophicum (1684). The same is true for his participation in the famous "friendly conversation" between himself and the leading Remonstrant theologian Philip van Limborch, a record of which Van Limborch published in 1687 under the title De veritate religionis Christianae amica collatio cum erudito Judaeo (1687).

Much could be said about that conversation, which, in brief, should not be considered quite as friendly as Limborch would have us regard it. However, my aspiration here isn't to refute Melnick's thesis (although, in fact, I would only accept it with

5 See, e. g. Saul Levi Mortera, Preguntas que se hizieron de un clerigo de Ruan a Amsterdam, University Library of Amsterdam, ms. Ros. 127. See also Melnick, Polemics, 29-32; Marc Saperstein, "Your Voice Like a Ram's Horn": Themes and Texts in Traditional Jewish Preaching (Cincinnati: Hebrew Union College Press, 1996), 118-125.

6 Israel, European Jewry, 154-156.

7 See A. K. Offenberg, "Jacob Jehuda Leon (1602-1675) and his Model of the Temple," in JewishChristian Relations in the Seventeenth Century: Studies and Documents, edited by Jan van den Berg and Ernestine van der Wall (Dordrecht: Kluwer, 1988): 101-110.

8 Ernestine G. E. van der Wall, "The Amsterdam Millenarian Petrus Serrarius (1600-1669) and the Anglo-Dutch Circle of Philo-Judaists," in Jewish-Christian Relations in the Seventeenth Century: 73-94. 9 Yosef Kaplan, From Christianity to Judaism: The Story of Isaac Orobio de Castro (Oxford: Littman Library, 1989). 
caution and with caveats), but, rather, to offer a sequel to it, looking forward from the late seventeenth century to the third quarter of the eighteenth century. Over that later period, the trend observed by Melnick is, if anything, thrown into reverse.

\section{Jewish-Christian Rapprochement and its Reversal}

The "polite conversation" of the 1680s, I would argue, marked the effective end of the strategy of Christian intellectual leaders, born with the disputations of the thirteenth century, to establish the truth of Christianity and the falsity of Judaism through structured debate between representatives of the two religions. For the next eighty years, Jewish arguments continued to resonate powerfully in non-Jewish thought. But they did so in a disembodied form, with little sense of their connection to a living, contemporary Judaism; and they did so with an increasingly hardened polemical edge, directed simultaneously against institutionalised Christianity and against Judaism itself. This is a complex story that can be grasped by tracing the reception and use of Orobio's works during the eighteenth century, when they were coopted into the polemical arsenal of the radical French Enlightenment. The rapprochement between Jews and Christians that Melnick observes in seventeenth-century Amsterdam was, in a sense ironically, what enabled this process to get underway.

Although any theological rapprochement was more hesitant than Melnick suggests, it was certainly the case that social contacts at an elite level became much more relaxed over the course of the century. In the period after the Shabbatai Zevi affair, Christian interest in Judaism became less fervid, and was increasingly moulded by the more sober scholarly concerns of the Republic of Letters. In this intellectual climate, Jewish philosophical and theological arguments were explored with a new meticulousness and sense of fascination. By the end of the seventeenth century, it was possible for determined Christian intellectuals, particularly in Holland, to gain access to a range of Jewish anti-Christian texts by Montalto, Mortera, Orobio, and others. The circulation of these manuscripts within the Sephardic community was an open secret, and it seems very likely that leading Dutch Sephardic patricians on occasion proudly showed their sumptuously calligraphed volumes to selected Christian savant acquaintances. ${ }^{10}$

These polemics were written to address specific doubts and uncertainties within the Sephardic community and were intended for an exclusively Jewish readership. However, there is evidence of Christian access to them from as early as the 1630s: Constantijn l'Empereur, Professor of Hebrew at Leiden from 1627 to 1646, possessed several Jewish polemics and mentioned in his correspondence that he was engaged

10 On Jewish/non-Jewish sociability in this period, see Jonathan I. Israel, "Gregorio Leti (1631-1701) and the Dutch Sephardi Elite at the close of the Seventeenth Century," in Jewish History: Essays in Honour of Chimen Abramsky, edited by Ada Rapaport-Albert and Steven Zipperstein (London: Peter Halban, 1988): 267-284. 
in translating one of them into Latin. ${ }^{11}$ The Amica Collatio drew enduring interest across much of Europe in the early eighteenth century. ${ }^{12}$ Other Sephardic anti-Christian polemics also at this time attracted significant attention from Early Enlightenment intellectuals. Several such manuscripts were sold at high prices at the auction in The Hague in 1715 of the "Biblioteca Sarraziana," the vast private library of G. L. de la Sarraz, a Protestant minister and bibliophile. ${ }^{13}$ Jacques Basnage, who was Sarraz's father-in-law, eagerly took the opportunity to consult the library just before its sale, and incorporated much new material from the polemics of Orobio, Mortera, Montalto and Menasseh ben Israel into the third edition of his Histoire des Juifs (1716). ${ }^{14}$ Basnage treated these texts as striking intellectual curiosities and described their contents in detail without attempting to offer any response to them. In more radical circles, however, the same texts were put to inventive and ingenious use.

\section{Lévesque de Burigny and the "Dissertation sur le Messie"}

The most intricate reception of Orobio's writings was within the world of early eighteenth-century French clandestine philosophy. The initiator of this was the deist Jean Lévesque de Burigny (1692-1785) who, while in Holland in 1720, made contact with learned Jews and had copies made of the anti-Christian texts by Orobio that they had showed him. ${ }^{15}$ He then returned to France, and, in collaboration with his friend Thémiseul de Saint-Hyacinthe, introduced these texts into clandestine circulation there. ${ }^{16}$ From the 1720 s onwards, French manuscript translations of Orobio's writings circulated in various forms and under a variety of titles. At least four distinct French

11 Peter van Rooden, “Constantijn l'Empereur's Contacts with the Amsterdam Jews and his Confutation of Judaism," in Jewish-Christian Relations: 63-64. See also Peter van Rooden, “A Dutch Adaptation of Elias Montalto's Tractado Sobre o Principio do Capitulo 53 de Jesaias,” Lias 16 (1989): 189204.

12 See Jonathan I. Israel, Radical Enlightenment: Philosophy and the Making of Modernity 1650-1750 (Oxford: Oxford University Press, 2002), 615, 688-690.

13 Richard H. Popkin, “Jacques Basnage’s Histoire des Juifs and the Biblioteca Sarraziana," Studia Rosenthaliana 21 (1987): 154-162.

14 Popkin, “Jacques Basnage,” 157-158; Jacques Basnage, Histoire des Juifs depuis Jésus-Christ jusqu'à présent, pour servir de continuation à l'histoire de Joseph. Nouvelle édition augmentée (The Hague: Henri Scheurleer, 1716) IX, $1043 \mathrm{ff}$.

15 Burigny describes this encounter in a much later letter; see Ira O. Wade, The Clandestine Organization and Diffusion of Philosophic Ideas in France, 1700 - 1750 (Princeton: Princeton University Press, 1938), 229-230.

16 Miguel Benítez, "Orobio de Castro et la littérature clandestine," in La Face cachée des lumières: Recherches sur les manuscrits clandestins de l'âge classique (Oxford: Voltaire Foundation, 1996): 147154, here 150-151; Elisabeth Carayol, Thémiseul de Saint-Hyacinthe, 1684-1746 (Oxford: Voltaire Foundation at the Taylor Institution, 1984), 94, 142-145. 
clandestine texts are preserved, consisting largely of translations or excerpts from his Spanish works. ${ }^{17}$ To the radical readers of these manuscripts, the writings of Orobio and other Jewish controversialists constituted a rich and intriguing seam of arguments against Christian orthodoxy, readily mined for subversive use. However, the specifically Jewish flavour of the texts complicated their reception and was handled in a variety of ways. While at times Orobio's Jewishness was subtly erased from the manuscript translations, at other times it was deliberately highlighted in order to create a sense of daring, exoticism, indeterminacy or irony.

Measured by the number of extant copies, the most widely circulated manuscript based on Orobio's writings was Dissertation sur le Messie. Eight copies of this text, between some of which there are variations in wording but not in essential content, were enumerated by Miguel Benitez in the catalogue of clandestine manuscripts in his 1996 volume, La face cachée des Lumieres. ${ }^{18}$ The main body of this manuscript consisted of a loose translation of selected chapters of Orobio's Prevenciones Divinas, his most trenchant attack on the doctrines of Christianity, which had circulated widely within late seventeenth-century Sephardic Jewry. In the introduction to his text, Orobio states that he first presented his arguments in a debate with some Carmelite friars. According to Yosef Kaplan, this encounter probably did take place (though we cannot be sure), most likely in Brabant or elsewhere in the southern Netherlands. Kaplan dates the text to between 1668 and $1675 .^{19}$

Orobio is responding in the Prevenciones to a challenge posed to him by the Carmelites (or, possibly, rhetorically posed by himself and ventriloquistically ascribed to the Carmelites): Why didn't God, in his omniscience, warn his chosen people about the challenge they would later face from Christianity? Orobio's answer, in essence, is: He did! In the first chapter of the Prevenciones, Orobio addressed this challenge directly. The chapter is titled "Proof that in the five books of the law God forewarned Israel against all the idolatries of the gentiles, and against the philosophical arguments the Trinity that the Christians would invent." ${ }^{20}$ Orobio here opens his argument by arguing that, although biblical prophecy did not specifically refer to Christianity, or indeed to any specific pagan falsehood or idolatry, nonetheless "the lord God forewarned his beloved people in the divine law that is the archive and sum of all prophecy: there they were clearly taught enough not to accept and to dismiss the

17 See items 30 / C XIV, 67 / D XXXIII, 91 / E XVIII, 145 / P VIII and 234 in the inventory in Benítez, Face cachée, 20 - 61. See also Benítez, "Orobio"; Anthony McKenna, "Sur l'hérésie dans la littérature clandestine,” Dix-huitième siècle 22 (1990) 301-313; Kaplan, Orobio, 451- 457.

18 For further details, including the locations of these manuscript copies, see Benitez, Face cachée, 33 [item 67].

19 Isaac Orobio de Castro, Prevenciones divinas contra la vana idolatría de las gentes, ed. Myriam Silvera, Florence: Leo S. Olschki, 2013; Kaplan, Orobio, 243-245, 436-439 (for details of identified manuscript copies).

20 Orobio de Castro, Prevenciones divinas, vol. 1,20: "Prueva que en los Cinco Livros de la Ley previno Dios a Israel contra todas las idolatrías de las Gentes, contra los philósophos y contra la trinidad que avían de inventar los Christianos.” 
many idolatries and superstitions that could be invented by the wickedness or the ignorance of men in all ages."21 The ensuing text critiques various Christian doctrines, particularly the Trinity, and offers a detailed defence of the Jewish reading of key biblical prooftexts, especially Daniel's prophecy of the "seventy weeks" and Isaiah 53.

In the French version, the broad structure of Orobio's argument is followed, but the "translation" is so tendentious in many places that it barely qualifies as such. "Tendentious rewriting" would be a more accurate description. As an example, here is the first paragraph of the Dissertation sur le Messie:

God schooled the Israelites so well in the law that they had to follow that he judged it unnecessary to warn them of that which Jesus Christ would introduce several centuries after Moses. The pagans among whom this chosen people lived followed many religions and worshipped a plurality of Gods incompatible with the unity of the true God. Nowhere in the sacred text does one see that the Israelites were warned that false Gods would rise up capable of seducing them. The only precaution that the Lord took to protect his people from false doctrines consisted in the interdict that he made on their worship of Gods unknown to their ancestors, and in the order in which he commanded them to punish as false prophets all those who told them that they should abandon the holy laws and precepts that He had ordered them to follow in perpetuity. These sacred orders needed to suffice for the Israelites to condemn all dogmas that were not entirely in conformity with the irrevocable decrees of the Divinity. ${ }^{22}$

The satirical bite here is, I think, pretty clear. The God of the Hebrews relies on the authority of his orders and on fear to ensure that his chosen people remain loyal to his commandments; beyond that, he made no provision to protect them from seduction by pagans and Christians. Orobio's intent was rather different: to show that the "general precepts" embedded within the Divine Law were quite sufficient to equip the Jews to reject the falsehoods of others.

21 Orobio de Castro, Prevenciones divinas, vol. 1, 20 - 21: "las previno el Señor Dios a su amado pueblo en la Ley divina que es archivo y summa de toda la prophesia: ally vocalmente fueron enseñados de quanto bastó para no admitir y arros[j]ar de sí quantas idolatrías y supersticiones podía inventar la malicia o la ignorancia de los hombres en todos los tiempos."

22 Isaac Orobio, Israël vengé, ou Exposition naturelle des prophéties hébraïques que les chrétiens appliquent à Jésus, leur prétendu Messie, traduit sur le manuscrit par Henriquez (London, n.p., 1770), 200 - 201: "Dieu a si bien instruit les Israélites dans la loi qu'ils doivent suivre, qu'il a jugé inutile de les avertir de celle que Jésus Christ devoit introduire plusieurs siecles après Moïse. Les payens parmi lesquels ce peuple choisi vivoit, s'étoient fait des religions \& adoroient une pluralité de Dieux incompatible avec l'unité du vrai Dieu. On ne voit dans aucun endroit du texte sacré que les Israélites seroient avertis qu'il s'éleveroit de fausses Divinités propres à les séduire. Toute la précaution que le Seigneur a prise pour garantir son peuple des fausses doctrines consiste dans la défense qu'il lui fait d'adorer des Dieux que leurs peres n'ont point connus \& dans l'ordre qu'il lui intime de punir comme de faux Prophetes tous ceux qui lui annonceroient qu'il devoit s'écarter des divines loix \& des préceptes qu'il leur avoit ordonné de suivre à perpétuité. Ces ordres sacrés doivent suffire aux Israélites pour condamner tous les dogmes qui ne sont pas entiérement conformes aux décrets irrévocables de la Divinité." 
Moreover, the overall argument of Orobio's text is profoundly reframed by the introductory and concluding chapters of the French manuscript version that are clearly written by a non-Jewish, philosophically radical author. These framing chapters, most probably written by Lévesque de Burigny or one of his collaborators, combine to cast a powerfully ironic inflection on the main body of the text. Both interpolated chapters are written in faux-naï style in an anonymous first person voice. The author begins by lamenting the "absurd situation" of his ignorance of even a single letter of the language in which God dictated the Bible. In order to overcome this and to satisfy his zeal to follow the biblical commandments "as exactly as possible," he explains that he has turned to the best possible guides for help: "the most learned rabbis of our century."23 Expert instruction from the most learned rabbis has convinced him of the enduring authenticity of Judaism, and of the falsity of Christianity. He then summarises the anti-Christian arguments that are elaborated in the main body of the text drawn from Orobio. He dismisses the Trinity as contrary both to reason and Scripture and ridicules the claim that the coming of Jesus Christ abrogated all the laws and ceremonies that are "so clearly set out in the Pentateuch," arguing that such an arbitrary and unheralded change would suggest an imperfection in God and in his sacred law. ${ }^{24}$

This fulsome respect for the Mosaic Law, however, is manifestly ironic. The feigned innocence of the authorial voice is intended not to suggest genuine admiration for rabbinic learning but, on the contrary, to undermine Christianity by implying that Christian zeal logically leads to such absurdity. A truly devoted Christian, the text provocatively implies, should become a Jew.

In the light of this introduction, the chapters of the text translated from Orobio take on a highly ambiguous gloss. Purely as textual critique, the reader is invited to acknowledge the persuasiveness of their interpretive logic, which is presented as distinctively "rabbinic." The argumentative potency of this, however, is utterly reversed when the text is read in the ironic tone suggested by its introduction. Within the terms of scripturally-based religion, Orobio's arguments defeat those of the Christians. Far from suggesting the underlying validity of these arguments, their intention is to demonstrate the utter ridiculousness of all biblical reverence. Superficially, Judaism is presented as posing a telling challenge to Christian theology, but, more fundamentally, it is cast as a reductio ad absurdum of Christianity itself.

23 Isaac Orobio, Israël vengé, 189: "L'extrême desir que j’ai de suivre avec le plus d'exactitude possible ce que m’ordonne le texte sacré, m’a engagé à le lire avec toute l'attention dont je suis capable, \& pour m'en rendre encore l'intelligence plus facile, j'ai interrogé les plus sçavans Rabbins de notre siecle."

24 Isaac Orobio, Israël vengé, 196: "En un mot la nouvelle loi introduite depuis la venue de Jésus Christ abolit toutes les ordonnances légales, tous les preceptes, toutes les cérémonies \& tout le culte de Dieu si clairement énoncés dans le pentatheuque. Pourquoi les changemens? Qui peut les avoir authorisés? Y a-t-il de l'imperfection en Dieu? Nous a-t-il fixé un tems pour suivre sa loi sacrée \& nous a-t-il avertis d'en suivre une nouvelle après le terme expiré?” 
The ironic tone of the Dissertation sur le Messie is reaffirmed in its concluding editorial interpolation, once again in the voice of our anonymous narrator who here enthusiastically celebrates the revealed authority of Judaism, established in perpetuity at Sinai. Within the culture of French clandestine philosophy in this period, the irony of this argument is unmistakable: it was the most fundamental, radical tenet that faith should not be based on revelation, but on reason. In ostensibly lauding the Sinaitic "beatific vision" through which God had established and consolidated the faith of the Jews "for all eternity," 25 the text in fact pointedly ridicules the allegedly static, dogmatic and irrational nature of Judaism, and implies that Christianity, if pushed to its logical conclusions, is scarcely any different.

Here as well as in other manuscript versions of his texts, Orobio's arguments are wielded in an extremely mobile and double-edged manner. ${ }^{26}$ They are simultaneously used as a highly effective weapon against Christianity while being framed as even more absurd that the Christian beliefs against which they are deployed. Orobio's voice at times serves almost as a ventriloquistic mouthpiece for Early Enlightenment rationalism, while also representing an archetype of blinkered rabbinism. The Jewish speaking position in these manuscripts is both fundamentally unstable and deeply ironic. The latter captures a powerful subversive pleasure in using the arguments of a Jew to undermine Christian theology, and yet sustained identification with these arguments is never entertained in these texts. Repeatedly, Jewish victory is ironically undercut through its portrayal as the inverted triumph of a religion even more absurd than Christianity, as a result of the topsy-turvy logic of irrational scriptural fundamentalism.

\section{The Baron d'Holbach}

In 1770 there appeared the first printed edition of Orobio's anti-Christian writings, in French translation, under the title Israël vengé, ou Exposition naturelle des prophéties hébraïques que les chrétiens appliquent à Jésus, leur prétendu Messie. Presented straightforwardly as Orobio's own work, the publication was in fact sponsored by the radical materialist and atheist the Baron d'Holbach along with other members of his Parisian circle. ${ }^{27}$ The overwhelming majority of this text was in fact drawn from the earlier clandestine manuscript translations. The first section of Israël vengé is largely taken from a manuscript titled La divinité du Jésus-Christ détruite, it-

25 Isaac Orobio, Israël vengé, 243 : “cette voix divine, cette vision béatifique a établi \& consolidé leur foi pour toute l'eternité."

26 For a close examination of these texts, see Adam Sutcliffe, "Judaism and Jewish Arguments in the Clandestine Radical Enlightenment,” in Scepticisme, clandestinité et libre pensée, edited by Gianni Paganini, Miguel Benítez, and James Dybikowski (Paris: Champion, 2002): 97-113.

27 Alan Charles Kors, D'Holbach's Coterie: An Enlightenment in Paris (Princeton: Princeton University Press, 1976). 
self a free translation from an essay by Orobio on the fifty-third chapter of Isaiah (which in turn was largely based on a section on this topic in his Prevenciones). The second and final section, meanwhile, is simply a printing, under the same title, of the Dissertation sur le Messie.

Holbach's text carefully follows the rationalist logic of Orobio's critique of the Trinity and his exposure of the contradictions he sees as besetting this doctrine. However, through various subtle twists of language the French version discreetly but unmistakably distances itself from Orobio's Spanish original, lightly ridiculing his scriptural fealty while at the same time deploying it as an anti-Christian argument. D'Holbach was one of the most infamous radicals of the late Enlightenment and was an open atheist-in his most famous text, the System of Nature, also published in 1770, he advances the uncompromisingly materialist argument that everything in the universe is simply matter in motion. In his hands, Orobio's voice was diffused as one among many strategies through which he sought to undermine and ridicule organised religion in all its forms.

\section{Anthony Collins}

Beyond France, Jewish anti-Christian arguments attracted the attention of the English deists, above all Anthony Collins, whose immense library included manuscript apologetics in Spanish by Troki, Mortera, and Orobio. ${ }^{28}$ Collins' Discourse of the Grounds and Reasons of the Christian Religion (1724), in which he argues that the Old Testament prophecies can only lend support to Christianity if they are interpreted allegorically rather than literally, is clearly indebted to the detailed exegesis of the prophetical books of Daniel and Isaiah in Orobio's Prevenciones Divinas. ${ }^{29}$ In his later Scheme of Literal Prophecy Considered (1727), which he wrote in response to the scandalised outcry provoked by the Discourse, Collins more explicitly aligns himself with a "Jewish" insistence on the literal meaning of these biblical passages. He here attacks traditionalists such as Stillingfleet and Grotius for "playing upon words," in ignoring the literal sense of the prophecies that was clearly "intended by the writer," and instead supporting an allegorical interpretation. ${ }^{30}$

In his earlier texts, however, Collins' attitude towards Judaism appears somewhat more ambivalent. Praising Josephus in his Discourse of Freethinking (1713), Collins expresses regret that this great historian's talents were wasted on "such an illiterate, barbarous and ridiculous people." ${ }^{11}$ Despite his fascination with Jewish themes, there is no underlying stability to his view of Judaism. While drawing on

28 James O’Higgins, Anthony Collins: The Man and his Works (The Hague: Martinus Nijhoff, 1970), 26.

29 Anthony Collins, A Discourse of the Grounds and Reasons of the Christian Religion (London: n.p., 1724); see also O’Higgins, Anthony Collins, 155-199.

30 Anthony Collins, A Scheme of Literal Prophecy Considered (London: n.p., 1727), 251.

31 Anthony Collins, A Discourse of Freethinking (London: n.p., 1713), 157. 
Mortera and Orobio's literalist scriptural readings in order to challenge the Christian interpretation of biblical prophecy, Collins simultaneously argues in his Discourse of 1724 that the Talmud also diverged from the literal meaning of the Bible and that therefore the allegorical biblical readings of Jesus and his disciples were in some sense characteristically Jewish. He repeatedly divides the Jews into opposing camps by such means as drawing a sharp contrast between the ancient Sadducees and Pharisees. ${ }^{32}$ Such splitting enables him to identify within Judaism the source of both the pure essence of natural religion and the priestly obfuscations that first obscured this wisdom.

\section{Conclusion}

Although Jewish arguments against Christianity were of noteworthy importance in the Early Enlightenment, it is misleading to consider them, as scholars such as Richard Popkin and Silvia Berti have done, as "sources" of unbelief. ${ }^{33}$ The arguments of Orobio and others did not in themselves generate doubts in Christian minds, or even strengthen the opinions of radicals by providing them with new reasons to doubt the traditional truth claims of Christianity. Writers such as D'Holbach and Lévesque de Burigny enthusiastically deployed their arguments not because they found them straightforwardly convincing, but because they constituted an extremely intriguing and versatile polemical resource.

For the English Deists and, to an even greater extent, the French compilers of clandestine manuscripts, writing was a performative practice, at least as concerned with the gestural enactment of intellectual transgression as with the formulation of new philosophical truths. ${ }^{34}$ The simultaneous exoticism and familiarity of Judaism and its status within traditional Christian theology as both foundational and abhorrent made it a perfect site of symbolic confrontation and intellectual play. A characteristic mode of many clandestine manuscripts was layered argumentation in which superficial readings were undermined by more hidden ones. The subversive use of Judaism typically followed this pattern, functioning as a critique that was itself subject to critique. To the authors and readers of these texts, the logical instability of these arguments was overshadowed by their polemical power and by the intellectual pleasure of the paradoxes and inversions they produced.

32 Collins, Scheme, 20 -21; Collins, A Philosophical Inquiry Concerning Human Liberty (London: R. Robinson, 1717), 60-61.

33 See Richard H. Popkin, "Jewish Anti-Christian Arguments as a Source of Irreligion from the Seventeenth to the Early Nineteenth Century," in Atheism from the Reformation to the Enlightenment, edited by Michael Hunter and David Wootton (Oxford: Oxford University Press, 1992): 159-181; Silvia Berti, “At the Roots of Unbelief," Journal of the History of Ideas 56 (1995): 555-575.

34 See James A. Herrick, The Radical Rhetoric of the English Deists: The Discourse of Skepticism, 1680-1750 (Columbia, SC: University of South Carolina Press, 1997). 
There was, thus, a paradox at the core of Burigny and D’Holbach's use of Orobio. They were using his arguments to undercut Christianity while simultaneously seeking to ridicule and subvert those Jewish arguments. This self-undermining, inherently unstable form of argument was, to eighteenth-century readers, deliciously playful, mobile, and scandalous. It lacked, however, a clear grounding other than the flat assertion that all this theology was clearly nonsense. While critiquing mainstream Christianity, there was no space unequivocally external to this tradition on which deists and radicals could ground their arguments. While Judaism in some sense offered such a non-Christian point of departure, it also represented the most fundamental roots of the Judeo-Christian world view, in opposition to which these critics largely defined their intellectual project. The use of Jewish sources, in sum, highlighted internal fractures within the formulation of Enlightenment rationalism.

\section{Works Cited}

Basnage, Jacques. Histoire des Juifs depuis Jésus-Christ jusqu'à présent, pour servir de continuation à l'histoire de Joseph. Nouvelle édition augmentée. The Hague: Henri Scheurleer, 1716.

Benítez, Miguel. "Orobio de Castro et la littérature clandestine." In his La Face cachée des lumières: Recherches sur les manuscrits clandestins de l'âge classique, 147-154. Oxford: Voltaire Foundation, 1996.

Berti, Silvia. "At the Roots of Unbelief." Journal of the History of Ideas 56 (1995): 555-575.

Carayol, Elisabeth. Thémiseul de Saint-Hyacinthe, 1684-1746. Oxford: Voltaire Foundation at the Taylor Institution, 1984.

Collins, Anthony. A Discourse of Freethinking. London: n.p., 1713.

Collins, Anthony. A Discourse of the Grounds and Reasons of the Christian Religion. London: n.p., 1724.

Collins, Anthony. A Philosophical Inquiry Concerning Human Liberty. London: R. Robinson, 1717.

Collins, Anthony. A Scheme of Literal Prophecy Considered. London: n.p., 1727.

Cooperman, Bernard. "Eliahu Montalto's 'Suitable and Incontrovertible Propositions" In Jewish Thought in the Seventeenth Century, edited by Isadore Twersky and Bernard Septimus, 469-497. Cambridge: Harvard University Center for Jewish Studies, 1987.

Herrick, James A. The Radical Rhetoric of the English Deists: The Discourse of Skepticism, 1680-1750. Columbia: University of South Carolina Press, 1997.

Israel, Jonathan I. European Jewry in the Age of Mercantilism, 1550-1750. Oxford: Clarendon Press, 1985.

Israel, Jonathan I. "Gregorio Leti (1631-1701) and the Dutch Sephardi Elite at the close of the Seventeenth Century." In Jewish History: Essays in Honour of Chimen Abramsky, edited by Ada Rapaport-Albert and Steven Zipperstein, 267-284. London: Peter Halban, 1988.

Israel, Jonathan I. Radical Enlightenment: Philosophy and the Making of Modernity 1650-1750. Oxford: Oxford University Press, 2002.

Kaplan, Yosef. From Christianity to Judaism: The Story of Isaac Orobio de Castro. Oxford: Littman Library, 1989.

Kors, Alan Charles. D'Holbach's Coterie: An Enlightenment in Paris. Princeton: Princeton University Press, 1976. 
McKenna, Anthony. "Sur l'hérésie dans la littérature clandestine." Dix-huitième siècle 22 (1990): 301-313.

Melnick, Ralph. From Polemics to Apologetics: Jewish-Christian Rapprochement in Seventeenth-Century Amsterdam. Assen: Van Gorcum, 1981.

Montalto, Eliahu. Tractado do Doctor Montalto Sobre o principio do Capitulo 53 de Jesaias. University Library of Amsterdam, MS Ros 76.

Mortera, Saul Levi. Preguntas que se hizieron de un clerigo de Ruan a Amsterdam. University Library of Amsterdam, MS Ros 127

O'Higgins, James. Anthony Collins: The Man and his Works. The Hague: Martinus Nijhoff, 1970.

Offenberg, Adri K. "Jacob Jehuda Leon (1602-1675) and his Model of the Temple." In Jewish-Christian Relations in the Seventeenth Century: Studies and Documents, edited by Jan van den Berg and Ernestine van der Wall, 101-110. Dordrecht: Kluwer, 1988.

Orobio de Castro, Isaac. Israël vengé, ou Exposition naturelle des prophéties hébraïques que les chrétiens appliquent à Jésus, leur prétendu Messie, traduit sur le manuscrit par Henriquez. Edited by Baron d'Holbach. London: n.p., 1770.

Orobio de Castro, Isaac. Prevenciones divinas contra la vana idolatría de las gentes, ed. Myriam Silvera. Florence: Leo S. Olschki, 2013.

Popkin, Richard. "Jacques Basnage’s Histoire des Juifs and the Biblioteca Sarraziana." Studia Rosenthaliana 21 (1987): 154-162.

Popkin, Richard. "Jewish Anti-Christian Arguments as a Source of Irreligion from the Seventeenth to the Early Nineteenth Century." In Atheism from the Reformation to the Enlightenment, edited by Michael Hunter and David Wootton, 159-81. Oxford: Oxford University Press, 1992.

Rooden, Peter van. "A Dutch Adaptation of Elias Montalto's Tractado Sobre o Principio do Capitulo 53 de Jesaias." Lias 16 (1989): 189-204.

Rooden, Peter van. "Constantijn l'Empereur's Contacts with the Amsterdam Jews and his Confutation of Judaism." In Jewish-Christian Relations in the Seventeenth Century: Studies and Documents, edited by Jan van den Berg and Ernestine van der Wall, 63-64. Dordrecht: Kluwer, 1988.

Saperstein, Marc. "Your Voice Like a Ram's Horn": Themes and Texts in Traditional Jewish Preaching. Cincinnati: Hebrew Union College Press, 1996.

Sutcliffe, Adam. "Judaism and Jewish Arguments in the Clandestine Radical Enlightenment." In Scepticisme, clandestinité et libre pensée, edited by Gianni Paganini, Miguel Benítez, and James Dybikowski, 97-113. Paris: Champion, 2002.

Wade, Ira 0. The Clandestine Organization and Diffusion of Philosophical Ideas in France, 1700-1750. Princeton: Princeton University Press, 1938.

Wall, Ernestine G. E. van der. "The Amsterdam Millenarian Petrus Serrarius (1600-1669) and the Anglo-Dutch Circle of Philo-Judaists." In Jewish-Christian Relations in the Seventeenth Century: Studies and Documents, edited by Jan van den Berg and Ernestine van der Wall, 73-94. Dordrecht: Kluwer, 1988. 